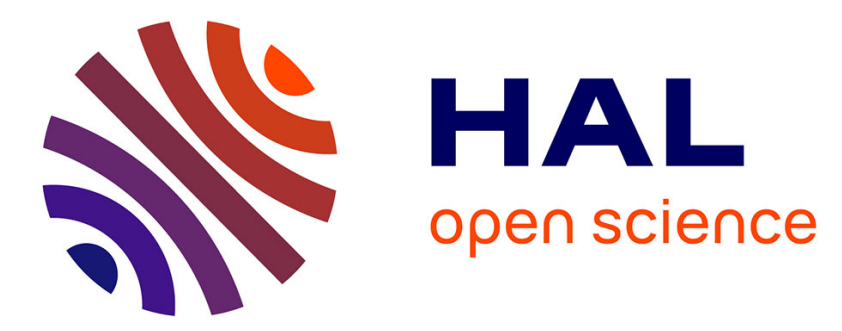

\title{
Effect of maturity on the phenolic compositions of pear juice and cell wall effects on procyanidins transfer
} Marwa Brahem, Severin Eder, Catherine M.G.C. Renard, Michele Loonis, Carine Le Bourvellec

\section{- To cite this version:}

Marwa Brahem, Severin Eder, Catherine M.G.C. Renard, Michele Loonis, Carine Le Bourvellec. Effect of maturity on the phenolic compositions of pear juice and cell wall effects on procyanidins transfer. LWT - Food Science and Technology, 2017, 85, pp.380-384. 10.1016/j.lwt.2016.09.009 hal-02619109

\section{HAL Id: hal-02619109 \\ https://hal.inrae.fr/hal-02619109}

Submitted on 25 May 2020

HAL is a multi-disciplinary open access archive for the deposit and dissemination of scientific research documents, whether they are published or not. The documents may come from teaching and research institutions in France or abroad, or from public or private research centers.
L'archive ouverte pluridisciplinaire HAL, est destinée au dépôt et à la diffusion de documents scientifiques de niveau recherche, publiés ou non, émanant des établissements d'enseignement et de recherche français ou étrangers, des laboratoires publics ou privés. 


\title{
Effect of maturity on the phenolic compositions of pear juice and cell wall effects on procyanidins transfer
}

\author{
Marwa Brahem*, Severin Eder, Catherine M.G.C. Renard, Michèle Loonis, \\ Carine Le Bourvellec \\ UMR408 SQPOV (Sécurité et Qualité des Produits d'Origine Végétale), INRA, Avignon University, F-84000 Avignon, France
}

\begin{abstract}
A B S T R A C T
Perry pear polyphenols were characterized in fruit, juice and pomace for two cultivars and at two maturity stage. Cell walls were characterized only in fruits and pomaces. The phenolic contents and compositions of fruits did not change during overripening. However, their extraction to juice was modified. Juices of ripe fruits contained 38\% (Plant de Blanc) and 28\% (De Cloche) of initial polyphenols, whereas overripe pear juices contained only $26 \%$ and $15 \%$ respectively. Thus, procyanidins had more affinity for cell walls after overripening. Pear cell walls from De Cloche cultivar lost arabinose and galactose from pectic side chains during overripening promoting non-covalent interactions between procyanidins and cell walls.
\end{abstract}

Keywords:

Pyrus communis L.

Juice

Condensed tannins

Pectic side chains

Overripening

\section{Introduction}

Perry pears are used in the west Midlands (UK) and in the regions of Bretagne and Normandie in France for the production of perry, a fermented fizzy beverage close to cider. They are specific cultivars characterized by their high content in polyphenols. Phenolic compounds have an important role in food industry. They contribute to flavor and color characteristics of fruit juices and wines (Spanos \& Wrolstad, 1990). Polyphenols are divided into several classes, i.e. phenolic acids (hydroxybenzoic acids and hydroxycinnamic acids), flavonoids (flavonols, flavones, flavanols, flavanones, isoflavones, proanthocyanidins), stilbenes, and lignans (Collin \& Crouzet, 2011). Procyanidins are the major polyphenols class in pear (dessert and perry pear cultivars) (Guyot, Marnet, Le Bourvellec, \& Drilleau, 2002; Le Bourvellec et al., 2013; Renard, 2005) where they contribute to astringency of perry. In perry processing, the use of fruit at the overripe stage is the normal practice to decrease the astringency and to increase colloidal

* Corresponding author. INRA, UMR408 SQPOV (Sécurité et Qualité des Produits d'Origine Végétale), 228 route de l'Aérodrome, CS 40509, F-84914 Avignon cedex 9, France.

E-mail addresses: marwabrahem90@yahoo.fr (M. Brahem), severin.eder@yahoo. de (S. Eder), catherine.renard@inra.fr (C.M.G.C. Renard), michele.loonis@inra.fr (M. Loonis), carine.le-bourvellec@inra.fr (C. Le Bourvellec). stability during storage. Further, preliminary studies have shown that the concentration of procyanidins in the juices varied with the fruit maturity at pressing (Alberti et al., 2016; Guyot, Marnet, Sanoner, \& Drilleau, 2003; Spanos \& Wrolstad, 1990). Low quantities of procyanidins are found in juices compared with the initial quantities measured in fruit (Guyot et al., 2002). Therefore, factors such as maturity that can induce change in the cell wall composition and structure can modulate the extractability of polyphenols and the organoleptic properties of perry.

The association between procyanidins and cell wall polysaccharides, especially pectins, can influence the transfer of procyanidins from fruit to juice (Guyot et al., 2003; Taira, Ono, \& Matsumoto, 1997). The binding of condensed tannins to cell walls depends on one hand on the molecular characteristics of procyanidins, mainly their degree of polymerization but also the pyranic ring stereochemistry of the flavan-3-ols, and on the other hand on cell wall structure and composition. Associations differ depending on neutral sugar composition and the structure of pectic fractions. Arabinogalactan had the lowest affinity for procyanidins (Watrelot, Le Bourvellec, Imberty, \& Renard, 2014). Watrelot, Le Bourvellec, Imberty, and Renard (2013) showed also that the strongest association was obtained with highly polymerized procyanidins and highly methylated pectins. The adsorption mechanism involves the establishment of non-covalent interactions, hydrogen bonds and hydrophobic interactions (Le Bourvellec, Bouchet, \& Renard, 2005; 
Version définitive du manuscrit publiée dans / Final version of the manuscript published in :

LWT - Food Science and Technology (2016), DOI: 10.1016/j.Iwt.2016.09.009

Journal homepage : http://www.elsevier.com/locate/lwtt.

Le Bourvellec, Guyot, \& Renard, 2004; Lea \& Arnold, 1978).

In general, cell wall modifications in ripening fruit involve hydrolysis of neutral sugars from side chains of pectin, depolymerization and increased solubilization of pectins (Brummell, 2006). Pear cell walls have a large heterogeneity compared to other fruits due to the presence of parenchyma and stone cells. Their cell walls have different polysaccharide compositions and evolve differently during ripening. In Spanish pears, changes were predominant in parenchyma cells and were accompanied by a decrease in pectic polysaccharides (arabinose, uronic acids) and an increase in their solubility (Martin-Cabrejas, Waldron, Selvendran, Parker, \& Moates, 1994). Those changes can affect differently the affinity of cell walls for procyanidins thus the organoleptic properties of pear juice.

The aim of this work was to determine the polyphenol and cell wall compositions of two perry pear cultivars at two different ripeness stages and to investigate the impact of maturity on polyphenol transfers in pear juices.

\section{Materials and methods}

\subsection{Chemicals and standards}

Acetonitrile, dichloromethane and acetone were obtained from VWR (Leuven, Belgium). Methanol, acetic acid, hydrochloric acid, sodium tetraborate, sodium hydroxide and sodium hydrogen carbonate were from Merck (Darmstadt, Germany). Sodium borohydride, $N$-methyl imidazole, potassium hydroxide, 3-phenylphenol, lignin, acetic anhydride, acetyl bromide, perchloric acid, chlorogenic acid, (+)-catechin, (-)-epicatechin, quercetin, isorhamnetin, hydroxylamine hydrochloride and benzyl mercaptan were provided by Sigma Aldrich (Steinheim, Germany). Sugar standards were from Fluka-Biochemica (Sigma Aldrich, Steinheim, Germany).

\subsection{Plant material}

Perry pear cultivars, "Plant de Blanc" and "De Cloche" were harvested in the experimental orchard of Institut Français des Productions Cidricoles (IFPC, Sées, France) on September 16 and October 5, 2015, respectively. They were stored at $1{ }^{\circ} \mathrm{C}$ until reaching the desired stage of maturity. Plant de Blanc pears were stored until September 22, De Cloche pears until October 8, 2015 to reach the ripe stage. The overripe stage was reached on October 21 for Plant de Blanc fruits, and on December 11, 2015 for De Cloche fruits.

\subsection{Preparation of samples}

Juice preparation from ripe and overripe pears was carried out by IFPC (Le Rheu, France).

The sugars/acids ratio serves as an industrial indicator because the balance between sugars and organic acids influences the taste of some beverages (Alberti et al., 2016; Pal \& Sampath Kumar, 1995). It was used in our case as a ripening index. Sugars and acids were determined as described by Le Bourvellec et al. (2015) and their ratio was then calculated. Overripening was marked by an increase of sugars/acids ratio especially for Plant De Blanc (Data not shown). Pears were washed and then crushed under $\mathrm{CO}_{2}$ atmosphere and with added sodium fluoride to prevent oxidation. Pears were pressed on a small laboratory high-pressure press (model HP5, 5 L, Hafico, Fischer and Co., Dusseldorf, Germany) for $15 \mathrm{~min}$. The hydraulic pressure was set at $4 \times 10^{7} \mathrm{~Pa}$, corresponding to an effective pressure of $234 \mathrm{~N} / \mathrm{m}^{2}$ on the plant material. For each cultivar and maturity $3 \times 1 \mathrm{~mL}$ of juice were collected after pressing, freeze-dried and stored at $-20{ }^{\circ} \mathrm{C}$ until analysis. Pomace samples, collected under $\mathrm{CO}_{2}$ atmosphere, were divided in two lots for polyphenols and cell walls analysis. Fresh fruits were cored and freeze dried in our laboratory (SQPOV, INRA, Avignon) and stored at $-20^{\circ} \mathrm{C}$.

\subsection{Analysis of phenolic compounds}

Polyphenols were determined in fruit, juice and pomace at two maturity stages by high performance liquid chromatography (HPLC/Diode Array Detection) with or without thioacidolysis as described by Guyot, Marnet, and Drilleau (2001) and Le Bourvellec et al. (2011).

\subsection{Cell walls preparation and characterization}

Alcohol Insoluble Solids (AIS) from fruit and pomace at the two maturity stages were prepared according to Renard (2005); neutral sugars, galacturonic acid and methanol were determined as described in Renard and Ginies (2009).

Lignin was analysed in AIS as described by Syros, Yupsanis, Zafiriadis, and Economou (2004) with some modifications. Samples (10-15 mg) were digested in $1 \mathrm{~mL}$ of buffer (250 mL/L acetyl bromide, $27 \mathrm{~mL} / \mathrm{L}$ perchloric acid and $723 \mathrm{~mL} / \mathrm{L}$ acetic acid). Then, samples were incubated for $30 \mathrm{~min}$ at $70{ }^{\circ} \mathrm{C} .10 \mu \mathrm{L}$ for each sample were added to $570 \mu \mathrm{L}$ of a solution of [172.4 mL/L of $\mathrm{NaOH} 2 \mathrm{~mol} / \mathrm{L}$ and $827.6 \mathrm{~mL} / \mathrm{L}$ of acetic acid] and $20 \mu \mathrm{L}$ of $7.5 \mathrm{~mol} / \mathrm{L}$ hydroxylamine hydrochloride to stop the reaction. The volume was corrected to $2 \mathrm{~mL}$ with acetic acid and the absorbance was read at $280 \mathrm{~nm}$ using a spectrophotometer V-730 (Jasco, Tokyo, Japan).

\subsubsection{Statistics}

Results are presented as mean values, and the reproducibility of the obtained results was expressed by pooled standard deviation (Pooled SD) (Box, Hunter, \& Hunter, 1978). One-way analysis of variance (ANOVA) was performed on perry pear fruit, juice and pomace polyphenol compositions concerning ripeness using the Excel Stat package of Microsoft Excel.

\section{Results and discussion}

\subsection{Phenolic composition of perry pears, juice and pomace}

The phenolic composition of fruits, juices and pomaces and their changes during overripening for Plant De Blanc and De Cloche cultivars are summarized in Table 1.

Procyanidins were the predominant phenolic class, with between 6 and $8 \mathrm{~g} / \mathrm{kg} \mathrm{FW}$, higher than reported by Le Bourvellec et al. (2013) in William pears (dessert pears) and by Renard (2005) in Gieser Wildeman (cooking pears). Perry pear procyanidins had a high degree of polymerization ( $\mathrm{DPn}=20$ for De Cloche and $\mathrm{DPn}=33$ for Plant de Blanc fruits), as reported by Guyot et al. (2002). The only flavan-3-ols monomer detected was (-)-epicatechin as observed by Le Bourvellec et al. (2013). Hydroxycinammic acids were represented by 5-caffeolyquinic acid, which has been reported as the main hydroxycinammic acid in pears (Galvis Sánchez, Gil-Izquierdo, \& Gil, 2003; Le Bourvellec et al., 2013; Li et al., 2012; Yim \& Nam, 2016). Flavonols, located in the peel, mainly quercetin and isorhamnetin glucosides, were present in low quantities $<40 \mathrm{mg} / \mathrm{kg}$ FW for both cultivars. No significant changes in polyphenol concentrations, neither procyanidins nor flavonols, were detected during fruit overripening, irrespective of the cultivar.

Juice concentrations decreased almost by half for De Cloche and slightly less for Plant De Blanc after overripening. This decrease was mainly due to decrease in procyanidins, as observed by Guyot et al. (2002). Decrease of the degree of polymerization was observed for 
Version définitive du manuscrit publiée dans / Final version of the manuscript published in :

LWT - Food Science and Technology (2016), DOI: 10.1016/j.Iwt.2016.09.009

Journal homepage : http://www.elsevier.com/locate/lwt

Table 1

Polyphenol compositions and concentrations in the fruits, pomaces (mg/kg of fresh weight FW) and in the juices (mg/L of fresh weight FW) of two perry pear cultivars.

\begin{tabular}{|c|c|c|c|c|c|c|c|c|}
\hline Cultivars & Tissue & Maturity & EC & PCA & DPn & CQA & Flavonols & Total \\
\hline Plant de Blanc & Fruit & Ripe & 30 & 7390 & 33 & 796 & 29 & 8240 \\
\hline Plant de Blanc & Fruit & Overripe & 26 & 8020 & 37 & 926 & 31 & 9000 \\
\hline Pooled SD & & & 1.2 & 352 & 1.0 & 24.68 & 5.7 & 378 \\
\hline Significance & & & $*$ & $n s$ & $*$ & $*$ & $n s$ & $n s$ \\
\hline Plant de Blanc & Juice & Ripe & 7 & 4060 & 44 & 624 & 2 & 4690 \\
\hline Plant de Blanc & Juice & Overripe & n.d. & 2780 & 38 & 573 & 2 & 3360 \\
\hline Pooled SD & & & 0.1 & 67.1 & 1.1 & 13.7 & 0.5 & 80.1 \\
\hline Significance & & & $* * *$ & $* * *$ & $* * *$ & $*$ & $n s$ & $* * *$ \\
\hline Plant de Blanc & Pomace & Ripe & 109 & 14,000 & 28 & 1480 & 145 & 15600 \\
\hline Plant de Blanc & Pomace & Overripe & 110 & 16,300 & 26 & 1610 & 136 & 18,100 \\
\hline Pooled SD & & & 6.5 & 302 & 1.0 & 82.0 & 15.2 & 392 \\
\hline Significance & & & ns & $* *$ & $n s$ & ns & $n s$ & * \\
\hline De Cloche & Fruit & Ripe & 60 & 6660 & 20 & 318 & 35 & 7080 \\
\hline De Cloche & Fruit & Overripe & 40 & 5880 & 21 & 289 & 31 & 6240 \\
\hline Pooled SD & & & 4.0 & 429 & 1.2 & 18.2 & 7.8 & 456 \\
\hline Significance & & & $*$ & $n s$ & $n s$ & $n s$ & $n s$ & $n s$ \\
\hline De Cloche & Juice & Ripe & 21 & 2660 & 20 & 260 & 4 & 2940 \\
\hline De Cloche & Juice & Overripe & 16 & 1450 & 14 & 216 & 3 & 1690 \\
\hline Pooled SD & & & 0.4 & 167 & 0.4 & 25.8 & 0.2 & 192 \\
\hline Significance & & & $* * *$ & $* * *$ & $* * *$ & $*$ & $n s$ & $* * *$ \\
\hline De Cloche & Pomace & Ripe & 93 & 10,700 & 13 & 500 & 66 & 11,400 \\
\hline De Cloche & Pomace & Overripe & 93 & 12,700 & 16 & 387 & 48 & 13,300 \\
\hline Pooled SD & & & 4.4 & 200 & 0.3 & 30.3 & 5.0 & 175 \\
\hline Significance & & & $n s$ & $* *$ & $* *$ & $*$ & $*$ & ** \\
\hline
\end{tabular}

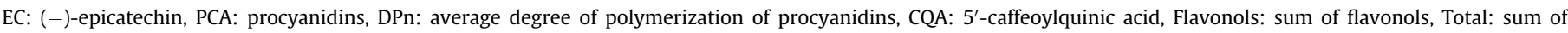
polyphenols, n.d.: not detected, Pooled SD: pooled standard deviation, ns: not significant $(\mathrm{P}>0.05),{ }^{* * *}: \mathrm{P}<0.0001,{ }^{* *}: \mathrm{P}<0.01,{ }^{*}: \mathrm{P}<0.1$.

both cultivars. The reduction in 5-caffeolyquinic acid was less marked than for procyanidins. Flavonol concentrations in the juice for both cultivars were about 10 times lower than in the fruit, but were not affected by overripening.

In parallel, some polyphenols were retained in overripe pear pomace. Procyanidins, with lower DP than in fruit and juice, increased to $>10 \mathrm{~g} / \mathrm{kg}$ FW. The sum of flavonols was higher than in fruit and juice, between $48 \mathrm{mg} / \mathrm{kg}$ FW and $145 \mathrm{mg} / \mathrm{kg}$ FW for overripe De Cloche and ripe Plant De Blanc respectively, linked to the enrichment of pomace in peel and their low extractability. 5caffeolyquinic acid was present in higher amounts than fruit and juice (387-1610 mg/kg FW for overripe De Cloche pomace and overripe Plant De Blanc pomace respectively).

\subsection{Composition of alcohol insoluble solids (AIS)}

Yields, carbohydrate compositions of AIS from fruits and pomaces at the two maturity stages are presented in Table 2 .

Fruit AIS represented $43-48 \mathrm{~g} / \mathrm{kg}$ fresh weight (FW) in ripe and overripe pears. Yields found here were relatively high than those found in other pear cultivars because cell walls were extracted from whole fruits but were comparable to those reported by Raffo,
Ponce, Sozzi, Vicente, and Stortz (2011) for Bartlett pears. The AIS yields obtained by Le Bourvellec et al. (2013), Martin-Cabrejas, Waldron, \& Selvendran (1994), Jermyn and Isherwood (1956) from the flesh of William, Blanquille and Conference pears were close to $30 \mathrm{~g} / \mathrm{kg}$ and were relatively higher than yields obtained by Renard (2005) for Gieser Wildemann pears. The main sugars in the AIS of both pears cultivars at both maturity stages were glucose (192-284 mg/g), xylose (140-176 mg/g) and galacturonic acid $(108-118 \mathrm{mg} / \mathrm{g})$. Arabinose and galactose were found in lower amounts (34-79 $\mathrm{mg} / \mathrm{g}$ and $36-70 \mathrm{mg} / \mathrm{g}$ respectively), whereas rhamnose, fucose and mannose were minor compounds. The degree of methylation of pectin was $>50$. The composition was close to that reported by Martin-Cabrejas, Waldron, Selvendran, Parker, et al. (1994) on Banquille pears and by Renard (2005) on Gieser Wildemann pears. During AIS preparation, procyanidins bind spontaneously to cell walls by $\mathrm{H}$-bonds and hydrophobic interactions (Renard, Baron, Guyot, \& Drilleau, 2001). There were high concentrations of retained procyanidins $(20-43 \mathrm{mg} / \mathrm{g}$ ) with high degree of polymerization varied between 41 and 65. Pear cell walls contained also high quantities of lignin $(212-232 \mathrm{mg} / \mathrm{g})$. The high concentrations of glucose, xylose and lignin reflected the presence of lignified cell walls rich in xylans and cellulose, typical of

Table 2

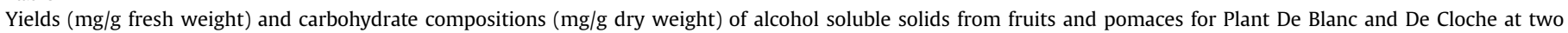
maturity stages.

\begin{tabular}{|c|c|c|c|c|c|c|c|c|c|c|c|c|c|c|}
\hline Cultivar & Material & Maturity & Yields & Rha & Fuc & Ara & Xyl & Man & Gal & Glc & Gal A & $\mathrm{MeOH}(\mathrm{DM})$ & Lig & PCA (DP) \\
\hline \multirow[t]{4}{*}{ Plant de Blanc } & Fruit & Ripe & 46 & 5 & 2 & 57 & 161 & 7 & 25 & 284 & 108 & $11(56)$ & 212 & $20(63)$ \\
\hline & & Overripe & 43 & 6 & 2 & 56 & 173 & 7 & 24 & 194 & 118 & $11(51)$ & 232 & $43(65)$ \\
\hline & Pomace & Ripe & 220 & 7 & 2 & 61 & 133 & 8 & 28 & 287 & 124 & $12(54)$ & 170 & $14(31)$ \\
\hline & & Overripe & 190 & 6 & 3 & 64 & 154 & 8 & 26 & 177 & 104 & $13(65)$ & 202 & $21(39)$ \\
\hline \multirow[t]{4}{*}{ De Cloche } & Fruit & Ripe & 43 & 5 & 3 & 79 & 140 & 7 & 38 & 263 & 113 & $12(57)$ & 211 & $30(48)$ \\
\hline & & Overripe & 48 & 6 & 2 & 34 & 176 & 7 & 19 & 192 & 111 & $11(55)$ & 226 & $40(41)$ \\
\hline & Pomace & Ripe & 209 & 7 & 2 & 70 & 161 & 6 & 35 & 233 & 120 & $13(60)$ & 167 & $14(26)$ \\
\hline & & Overripe & 162 & 7 & 2 & 36 & 172 & 7 & 19 & 178 & 120 & $13(60)$ & 237 & $27(40)$ \\
\hline Pooled SD & & & 3.5 & 0.5 & 0.1 & 2.2 & 7.4 & 0.3 & 1.4 & 9.7 & 5.8 & $0.5(3.5)$ & 7.1 & $0.6(1.4)$ \\
\hline
\end{tabular}

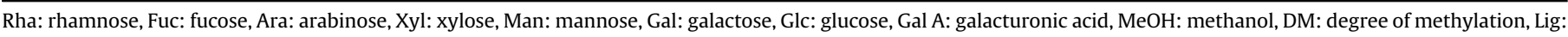
lignin, PCA: procyanidins, DP: degree of polymerization of procyanidins, Pooled SD: pooled standard deviation. 
stone cells (Ben-Arie, Kislev, \& Frenkel, 1979; Martin-Cabrejas, Waldron, Selvendran, Parker et al., 1994). Le Bourvellec et al. (2013) detected more galacturonic acid and less xylose in the AIS from the flesh of William pears.

The AIS contents of the remaining pomace varied from $162 \mathrm{~g} /$ $\mathrm{kg}$ FW to $220 \mathrm{~g} / \mathrm{kg}$ FW and were 5 times higher than in pears, as observed for plum pomace by Kosmala et al. (2013). Accumulation of peel and seeds in the pomace further increased the AIS, as both contain more AIS than parenchyma, as reported e.g. for apples during processing into applesauce (Le Bourvellec et al., 2011). The composition of pomace AIS was close to that of fruit, with slightly higher galacturonic acid and lower lignin and procyanidins.

Overripening was marked by a clear loss (about 50\%) of arabinose and galactose for De Cloche cultivar. This was in agreement with Ahmed and Labavitch (1980) on Bartlett pears. Rhamnose, fucose and mannose did not vary during overripening, in accordance with previous work (Ahmed \& Labavitch, 1980; MartinCabrejas, Waldron, Selvendran, Parker et al., 1994). For both perry pear cultivars, a significant decrease of the total glucose amount was observed due to solubilization during ripening. An increase of xylose content was observed mainly for De Cloche Cultivar. Lignin was found in higher amounts with ripening, consistent with the formation of lignified cell walls (Martin-Cabrejas, Waldron, Selvendran, Parker et al., 1994). For pomace, changes in the sugar compositions were not drastic and similar to those noted on fruit AIS. The amounts of bound procyanidins increased from ripe to overripe for both fruits and pomaces. Only highly polymerized procyanidins (DP $>40$ for De Cloche and DP $>60$ for Plant De Blanc) were bound essentially in fruit AIS.

\subsection{Impact of cell walls on procyanidins transfer in juice}

The lower quantities of phenolic compounds in juices compared to fruits could be explained by the retention of phenolic compounds by cell wall polysaccharides (Alberti et al., 2016; Le Bourvellec, Le Quere, \& Renard, 2007), considering that mostly procyanidins remained in the pomace. Procyanidins can be selectively adsorbed by cell wall polysaccharides. This has been reported for apple and grape (Bindon, Smith, \& Kennedy, 2010; Renard et al., 2001; Ruiz-Garcia, Smith, \& Bindon, 2014) where procyanidins complexation with cell walls was found to be spontaneous and rapid (Renard et al., 2001).

Three phenomena can explain increased binding of procyanidins to cell walls from overripe pears. First, the loss of arabinose and galactose indicated a loss of pectin side chains. Watrelot et al. (2014) show that these pectin side chains have low affinity for procyanidins, hence their elimination and better access to pectin's rhamnogalacturonic backbone can contribute to increase affinity. Second, during overripening solubilization and loss of polysaccharides from cell wall might increase its porosity (Bindon, Madani, Pendleton, Smith, \& Kennedy, 2014) so that more surface become available for binding of procyanidins. Thirdly, overripening seemed to promote interaction between pear procyanidins and cell walls. In over ripened fruit some membrane breakdown might start to occur, so that procyanidins might come in contact with cell walls prior to pressing.

\section{Conclusion}

Overripening of perry pears was demonstrated to decrease the extraction of procyanidins to the juice in spite of constant concentration in the fruit. This justifies the use of overripe pears by the perry producers. The same mechanisms seem to be present in pears as in grape (for wine production) or apple (for cider production). This indicates a generic mechanism that can be used to manipulate bitterness and astringency of fruit juices and might be an alternative to fining.

\section{Acknowledgements}

The authors thank "Institut Français des Productions Cidricoles" (Sées, France) for the supply of pears and juice production. We thank also Mrs Line Touloumet and Marielle Boge for their technical help. Marwa Brahem was supported by a PhD grant (RB35-2476) from the Higher Ministry of Education and Scientific Research of Tunisia.

\section{Appendix A. Supplementary data}

Supplementary data related to this article can be found at http:// dx.doi.org/10.1016/j.lwt.2016.09.009.

\section{References}

Ahmed, A. E., \& Labavitch, J. M. (1980). Cell wall metabolism in ripening fruit I. Cell wall changes in ripening Bartlett pears. Plant Physiology, 65(5), 1009-1013.

Alberti, A., dos Santos, T. P. M., Zielinski, A. A. F., dos Santos, C. M. E., Braga, C. M., Demiate, I. M., et al. (2016). Impact on chemical profile in apple juice and cider made from unripe, ripe and senescent dessert varieties. LWT-Food Science and Technology, 65, 436-443.

Ben-Arie, R., Kislev, N., \& Frenkel, C. (1979). Ultrastructural changes in the cell walls of ripening apple and pear fruit. Plant Physiology, 64(2), 197-202.

Bindon, K. A., Madani, S. H., Pendleton, P., Smith, P. A., \& Kennedy, J. A. (2014). Factors affecting skin tannin extractability in ripening grapes. Journal of Agricultural and Food Chemistry, 62(5), 1130-1141.

Bindon, K. A., Smith, P. A., \& Kennedy, J. A. (2010). Interaction between grapederived proanthocyanidins and cell wall material. 1. Effect on proanthocyanidin composition and molecular mass. Journal of Agricultural and Food Chemistry, 58(4), 2520-2528.

Box, G. E., Hunter, W. G., \& Hunter, J. S. (1978). Statistics for experimenters, an introduction to design, data analysis and model building. New York Wiley and Sons.

Brummell, D. A. (2006). Cell wall disassembly in ripening fruit. Functional Plant Biology, 33(2), 103-119.

Collin, S., \& Crouzet, J.. (2011). Polyphénols et procédés: Transformation des polyphénols au travers des procédés appliqués à l'agro-alimentaire (Lavaoisier ed.): Éd. Tec \& Doc.

Galvis Sánchez, A. C., Gil-Izquierdo, A., \& Gil, M. I. (2003). Comparative study of six pear cultivars in terms of their phenolic and vitamin $C$ contents and antioxidant capacity. Journal of the Science of Food and Agriculture, 83(10), 995-1003.

Guyot, S., Marnet, N., \& Drilleau, J.-F. (2001). Thiolysis-HPLC characterization of apple procyanidins covering a large range of polymerization states. Journal of Agricultural and Food Chemistry, 49(1), 14-20.

Guyot, S., Marnet, N., Le Bourvellec, C., \& Drilleau, J. (2002). Highly polymerised procyanidins in fruits and juices of perry pear (Pyrus communis) varieties. Polyphenols Communications, 2002, 463-464.

Guyot, S., Marnet, N., Sanoner, P., \& Drilleau, J.-F. (2003). Variability of the polyphenolic composition of cider apple (Malus domestica) fruits and juices. Journal of Agricultural and Food Chemistry, 51(21), 6240-6247.

Jermyn, M., \& Isherwood, F. (1956). Changes in the cell wall of the pear during ripening. Biochemical Journal, 64(1), 123.

Kosmala, M., Milala, J., Kołodziejczyk, K., Markowski, J., Zbrzeźniak, M., \& Renard, C. M. (2013). Dietary fiber and cell wall polysaccharides from plum (Prunus domestica L.) fruit, juice and pomace: Comparison of composition and functional properties for three plum varieties. Food Research International, 54(2), 1787-1794.

Le Bourvellec, C., Bouchet, B., \& Renard, C. M. G. C. (2005). Non-covalent interaction between procyanidins and apple cell wall material. Part III: Study on model polysaccharides. Biochimica et Biophysica Acta (BBA) - General Subjects, 1725(1), 10-18. http://dx.doi.org/10.1016/j.bbagen.2005.06.004.

Le Bourvellec, C., Bouzerzour, K., Ginies, C., Regis, S., Plé, Y., \& Renard, C. M. (2011) Phenolic and polysaccharidic composition of applesauce is close to that of apple flesh. Journal of Food Composition and Analysis, 24(4), 537-547.

Le Bourvellec, C., Bureau, S., Renard, C. M., Plenet, D., Gautier, H., Touloumet, L., \& Simon, S. (2015). Cultivar and year rather than agricultural practices affect primary and secondary metabolites in apple fruit. PloS One, 10(11), e0141916.

Le Bourvellec, C., Gouble, B., Bureau, S., Loonis, M., Plé, Y., \& Renard, C. M. G. C. (2013). Pink discoloration of canned pears: Role of procyanidin chemical depolymerization and procyanidin/cell wall interactions. Journal of Agricultural and Food Chemistry, 61(27), 6679-6692. http://dx.doi.org/10.1021/jf4005548.

Le Bourvellec, C., Guyot, S., \& Renard, C. M. G. C. (2004). Non-covalent interaction between procyanidins and apple cell wall material: Part I. Effect of some environmental parameters. Biochimica et Biophysica Acta (BBA) - General Subjects, 1672(3), 192-202. 
Version définitive du manuscrit publiée dans / Final version of the manuscript published in :

LWT - Food Science and Technology (2016), DOI: 10.1016/j.Iwt.2016.09.009

Journal homepage : http://www.elsevier.com/locate/lwt

Le Bourvellec, C., Le Quere, J.-M., \& Renard, C. M. G. C. (2007). Impact of noncovalent interactions between apple condensed tannins and cell walls on their transfer from fruit to juice: Studies in model suspensions and application. Journal of Agricultural and Food Chemistry, 55(19), 7896-7904.

Lea, A. G., \& Arnold, G. M. (1978). The phenolics of ciders: Bitterness and astringency. Journal of the Science of Food and Agriculture, 29(5), 478-483.

Li, X., Zhang, J.-Y., Gao, W.-Y., Wang, Y., Wang, H.-Y., Cao, J.-G., et al. (2012). Chemical composition and anti-inflammatory and antioxidant activities of eight pear cultivars. Journal of Agricultural and Food Chemistry, 60(35), 8738-8744.

Martin-Cabrejas, M. A., Waldron, K. W., \& Selvendran, R. R. (1994). Cell wall changes in spanish pear during ripening. Journal of Plant Physiology, 144(4-5), 541-548.

Martin-Cabrejas, M. A., Waldron, K. W., Selvendran, R. R., Parker, M. L., \& Moates, G. K. (1994). Ripening related changes in the cell walls of Spanish pear (Pyrus communis). Physiologia Plantarum, 91(4), 671-679.

Pal, D., \& Sampath Kumar, P. (1995). Changes in the physico-chemical and biochemical compositions of custard apple (Annona squamosa L.) fruits during growth, development and ripening. Journal of Horticultural Science, 70(4), $569-572$.

Raffo, M. D., Ponce, N. M. A., Sozzi, G. O., Vicente, A. R., \& Stortz, C. A. (2011) Compositional changes in 'Bartlett' pear (Pyrus communis L.) cell wall polysaccharides as affected by sunlight conditions. Journal of Agricultural and Food Chemistry, 59(22), 12155-12162. http://dx.doi.org/10.1021/jf203950d.

Renard, C. M. G. C. (2005). Effects of conventional boiling on the polyphenols and cell walls of pears. Journal of the Science of Food and Agriculture, 85(2), 310-318.

Renard, C. M. G. C. (2005). Variability in cell wall preparations: Quantification and comparison of common methods. Carbohydrate Polymers, 60(4), 515-522.

Renard, C. M. G. C., Baron, A., Guyot, S., \& Drilleau, J.-F. (2001). Interactions between apple cell walls and native apple polyphenols: Quantification and some consequences. International Journal of Biological Macromolecules, 29(2), 115-125.

Renard, C. M. G. C., \& Ginies, C. (2009). Comparison of the cell wall composition for flesh and skin from five different plums. Food Chemistry, 114(3), 1042-1049. http://dx.doi.org/10.1016/j.foodchem.2008.10.073.

Ruiz-Garcia, Y. Smith, P. A. \& Bindon, K. A. (2014). Selective extraction of polysaccharide affects the adsorption of proanthocyanidin by grape cell walls. Carbohydrate Polymers, 114, 102-114.

Spanos, G. A., \& Wrolstad, R. E. (1990). Influence of variety, maturity, processing and storage on the phenolic composition of pear juice. Journal of Agricultural and Food Chemistry, 38(3), 817-824.

Syros, T., Yupsanis, T., Zafiriadis, H., \& Economou, A. (2004). Activity and isoforms of peroxidases, lignin and anatomy, during adventitious rooting in cuttings of Ebenus cretica L. Journal of Plant Physiology, 161(1), 69-77. http://dx.doi.org/ 10.1078/0176-1617-00938.

Taira, S., Ono, M. \& Matsumoto, N. (1997). Reduction of persimmon astringency by complex formation between pectin and tannins. Postharvest Biology and Technology, 12(3), 265-271.

Watrelot, A. A., Le Bourvellec, C., Imberty, A., \& Renard, C. M. G. C. (2013). Interactions between pectic compounds and procyanidins are influenced by methylation degree and chain length. Biomacromolecules, 14(3), 709-718.

Watrelot, A. A., Le Bourvellec, C., Imberty, A., \& Renard, C. M. G. C. (2014). Neutral sugar side chains of pectins limit interactions with procyanidins. Carbohydrate Polymers, 99, 527-536.

Yim, S.-H., \& Nam, S.-H. (2016). Physiochemical, nutritional and functional characterization of 10 different pear cultivars (Pyrus spp.). Journal of Applied Botany and Food Quality, 89. 